Kurniawan, B., Sayuti, M., \& Kuat, T. (2018). The effectiveness of life skills education in fostering entrepreneurship values and interest of primary school students. Journal of Vocational Education Studies, 1(1), 21-28. DOI: https://doi.org/10.12928/joves.v1i1.592.

\title{
The effectiveness of life skills education in entrepreneurship values and interest of primary school students
}

\author{
${ }^{1}$ Bachtiar Kurniawan, Muhammad Sayuti², Tri Kuat ${ }^{2}$ \\ 1SD Muhammadiyah Bodon, Jagalan, Banguntapan, Bantul, DIY, Indonesia \\ ${ }^{2}$ Universitas Ahmad Dahlan, Jl. Pramuka 42, Sidikan, Yogyakarta, Indonesia \\ *Corresponding author, e-mail: bachtiar.kurniawan@gmail.com
}

\begin{abstract}
Entrepreneurship is believed as one of the pivotal attributes in a more competitive world. Therefore, early education to foster entrepreneurial values is fundamental in primary education. The purpose of this research is to find out and analyze the effect of life skills education in fostering entrepreneurship values and interest of elementary school students. Life skills education in this study cover in school entrepreneurial activities which include batik learning, cooking, and stringing. The entrepreneurship values are measured by eight indicators of self-directing, creativity, risk taking, leadership, honesty, responsibility, team work and communication. In the current study, students' interest in entrepreneurship are indicated by four indicators of contented, affection, involvement and attention. The methods used in this research is quantitative survey research. The results of the analysis reveal that life skills education contributed to entrepreneurship values at the level of $\beta=0.316$, $t$ (3.377), $p<0.001$ and entrepreneurship interest $\beta=0.202 \mathrm{t}(2.308), \mathrm{p}<0.05$. It can be concluded that there was contribution of life skills educational in fostering entrepreneurship values of the primary school students. The R square produced in the Model Summary is 0.115 which means that life skills education contributes $11.5 \%$ in fostering entrepreneurship values while life skills education contributes $6 \%$ of students' interest in entrepreneurship.
\end{abstract}

Keywords: Entrepreneurship values and interest, Indonesia, Life skills education, Primary school.

\begin{abstract}
Abstrak
Kewirausahaan diyakini sebagai salah satu atribut penting dalam dunia yang lebih kompetitif. Oleh karena itu, pendidikan awal untuk menumbuhkan nilai-nilai wirausaha merupakan hal mendasar dalam pendidikan dasar. Tujuan dari penelitian ini adalah untuk mengetahui dan menganalisis pengaruh pendidikan kecakapan hidup dalam menumbuhkan nilai-nilai kewirausahaan dan minat siswa sekolah dasar. Pendidikan kecakapan hidup dalam penelitian ini mencakup kegiatan kewirausahaan sekolah yang meliputi pembelajaran membatik, memasak, dan merangkai. Nilai-nilai kewirausahaan diukur oleh delapan indikator pengarahan diri sendiri, kreativitas, pengambilan risiko, kepemimpinan, kejujuran, tanggung jawab, kerja tim, dan komunikasi. Dalam studi saat ini, minat siswa dalam kewirausahaan ditunjukkan oleh empat indikator puas, kasih sayang, keterlibatan dan perhatian. Metode yang digunakan dalam penelitian ini adalah penelitian survei kuantitatif. Hasil analisis mengungkapkan bahwa pendidikan kecakapan hidup berkontribusi terhadap nilai-nilai kewirausahaan pada tingkat $\beta=0,316, \mathrm{t}(3,377), \mathrm{p}<0,001$ dan minat berwirausaha $\beta=0,202 \mathrm{t}$ $(2,308), p<0,05$. Dapat disimpulkan bahwa ada kontribusi pendidikan kecakapan hidup dalam menumbuhkan nilai-nilai kewirausahaan siswa sekolah dasar. R square yang dihasilkan dalam Model Summary adalah 0,115 yang berarti bahwa pendidikan kecakapan hidup berkontribusi 11,5\% dalam mendorong nilai-nilai kewirausahaan, sementara pendidikan kecakapan hidup berkontribusi 6\% dari minat siswa dalam kewirausahaan.
\end{abstract}

Kata Kunci: Indonesia, Nilai dan minat berwirausaha, Pendidikan kecakapan hidup, Sekolah dasar.

\section{INTRODUCTION}

Humans require education in their life as they could develop themselves through the learning process. It is in line with the function of national education contained in the Law of the Republic of Indonesia No. 20 of 2003 about the system of national education (Ristekdikti, 2016) i.e. the development the ability to form character and the civilization of 
the peoples dignity in the framework of the intellectual life of the nation, aimed at the development of potential participants students in order to become a man of faith and piety to God Almighty, precious, healthy, have learned, accomplished, creative, independent, and become citizens of a democratic and accountable.

Indrasutanto (2017) mentioned that the tendency of learning at school is very theoretic and not related to the environment in which are not able to apply what is learned in school to solve the problems that exist in everyday life. The educational process nowadays tend to be on achieving mastery of the material in each subject and haven't come to the what and how of learning the connectedness in daily life and can be used to solve problems there, resulting in students becoming less eager in his studies because it felt no benefit from what he had learned.

The government through the Ministry of Education and Culture (MOEC, 2013) provides life skills education programs at all levels of education to accommodate the problems above. The introduction of life skills education on all types and level of education is basically driven by the assumption that the relevance of education with a real lifeless closely. Education life skills (life skills) is an education that gives personal skills, social skills, intellectual prowess, and Polytechnic skills for work or independent business (Ristekdikti, 2016). WHO (1993) mentions that life skills are abilities for adaptive and positive behavior that makes a person can complete everyday needs and challenges effectively.

The research at Harvard University United States shows that a person's success is not determined from the knowledge and technical ability (hard skills) only about 20\%, but more than the ability to manage self and others (soft skills) that is of $80 \%$ (Robles, 2012). The agency's research and development center mentioned that the cultivation of the values of entrepreneurship can be integrated into the process of learning a conditioned that the values can be the attitude and behavior in everyday life. Cunha \& Heckman (2007) estimate investment on non-cognitive skills are most effective is in its infancy ( 9 to 11 years) where productivity themselves became stronger when the kids grow up (Huber, Sloof, \& Van Praag, 2014). The role of families is important in fostering interest in entrepreneurship for learners. The entrepreneurship education can take place from an early age in the family environment. The result of the researchers' initiative do more research to find out the values and interest in entrepreneurship elementary school.

\section{RESEARCH METHOD}

The methods used in this research is quantitative research. This research was conducted at the primary school Muhammadiyah in Banguntapan which carry out educational learning life skills with the total sample as many as 100 respondents. Data collection through a questionnaire with Likert scale using the scoring measurement. The data analysis technique used is test validity and reliability of research statement then continued with normality test and linearity data obtained. After that hypothesis testing is done with a simple regression test.

\section{RESULTS AND DISCUSSION}

The test of the validity was done by correlating the respective score items with a score total. The total score is the sum of all items (See Table 1). Statement items correlated significantly with total scores indicate items that are capable of providing support in exposing what it wants to be disclosed if the value is $\operatorname{sig}<0.05$ then instrument or questions items correlated significantly towards the score total (declared valid).

Kurniawan, B., Sayuti, M., \& Kuat, T. (2018). The effectiveness of life skills education in fostering entrepreneurship values and interest of primary school students. Journal of Vocational Education Studies, 1(1), 21-28. DOI: https://doi.org/10.12928/joves.v1i1.592. 
Table 1. The validity test of the variables values entrepreneurship students

\begin{tabular}{|c|c|c|c|}
\hline No. & $\begin{array}{c}\text { Pearson } \\
\text { Correlation }\end{array}$ & Sig. & Remark \\
\hline 1 & 0,284 & 0,007 & Valid \\
\hline 2 & $-0,036$ & 0,739 & Invalid \\
\hline 3 & 0,373 & 0,000 & Valid \\
\hline 4 & 0,004 & 0,973 & Invalid \\
\hline 5 & 0,366 & 0,000 & Valid \\
\hline 6 & $-0,037$ & 0,733 & Invalid \\
\hline 7 & 0,235 & 0,026 & Valid \\
\hline 8 & 0,085 & 0,428 & Invalid \\
\hline 9 & 0,417 & 0,000 & Valid \\
\hline 10 & 0,258 & 0,014 & Valid \\
\hline 11 & 0,284 & 0,007 & Valid \\
\hline 12 & 0,375 & 0,000 & Valid \\
\hline 13 & 0,466 & 0,000 & Valid \\
\hline 14 & 0,456 & 0,000 & Valid \\
\hline 15 & 0,202 & 0,056 & Invalid \\
\hline 16 & 0,529 & 0,000 & Valid \\
\hline 17 & 0,341 & 0,001 & Valid \\
\hline 18 & 0,528 & 0,000 & Valid \\
\hline 19 & 0,393 & 0,000 & Valid \\
\hline 20 & 0,538 & 0,000 & Valid \\
\hline 21 & 0,186 & 0,080 & Invalid \\
\hline 22 & 0,443 & 0,000 & Valid \\
\hline 23 & 0,288 & 0,006 & Valid \\
\hline 24 & $-0,060$ & 0,572 & Invalid \\
\hline 25 & 0,500 & 0,000 & Valid \\
\hline 26 & 0,356 & 0,001 & Valid \\
\hline 27 & 0,574 & 0,000 & Valid \\
\hline 28 & 0,299 & 0,004 & Valid \\
\hline 29 & 0,522 & 0,000 & Valid \\
\hline 30 & 0,036 & 0,739 & Invalid \\
\hline
\end{tabular}

The reliability test is used to find out the level of consistently now being used so that the results are reliable. In this study, a test of reliability is measured by using a value from the Cronbach's Alpha, as presented in Table 2. 
Table 2. The test reliability of the variable values entrepreneurship students

\begin{tabular}{c|c|l}
\hline \hline $\begin{array}{c}\text { N of } \\
\text { items }\end{array}$ & $\begin{array}{c}\text { Cronbach's } \\
\text { Alpha }\end{array}$ & Remark \\
\hline 22 & 0,791 & Reliable \\
\hline \hline
\end{tabular}

The validity of the test results are shown in Table 1 above it can be concluded that based on the current significance of obtained from a 30th statement, there are 22nd statement that the value of significance $<0.05$ so the statement is declared valid as instruments of variable values entrepreneurship students. Table 2 shows the value of the Cronbach's Alpha test of reliability is 0.791 this indicates that the reliability question form (reliable).

The validity of the test results is against dependent variables to interest students entrepreneurship shows that the 13th statement to be tested has the value significance < 0.05 . The statement is declared valid as instruments of the now of variable interest student entrepreneurship (see Table 3). The value of the Cronbach's variable from the Alpha test of reliability is 0.791 it indicates in the reliable question form (see Table 4).

Table 3. The validity test of the variable interest in entrepreneurship students

\begin{tabular}{c|c|c|c}
\hline \hline No. & $\begin{array}{c}\text { Pearson } \\
\text { Correlation }\end{array}$ & Sig. & Remark \\
\hline 1 & 0,596 & 0,000 & Valid \\
\hline 2 & 0,550 & 0,000 & Valid \\
\hline 3 & 0,485 & 0,000 & Valid \\
\hline 4 & 0,409 & 0,000 & Valid \\
\hline 5 & 0,515 & 0,000 & Valid \\
\hline 6 & 0,623 & 0,000 & Valid \\
\hline 7 & 0,416 & 0,000 & Valid \\
\hline 8 & 0,358 & 0,001 & Valid \\
\hline 9 & 0,473 & 0,000 & Valid \\
\hline 10 & 0,480 & 0,000 & Valid \\
\hline 11 & 0,262 & 0,013 & Valid \\
\hline 12 & 0,395 & 0,000 & Valid \\
\hline 13 & 0,514 & 0,000 & Valid \\
\hline \hline
\end{tabular}

Kurniawan, B., Sayuti, M., \& Kuat, T. (2018). The effectiveness of life skills education in fostering entrepreneurship values and interest of primary school students. Journal of Vocational Education Studies, 1(1), 21-28. DOI: https://doi.org/10.12928/joves.v1i1.592. 
Table 4. The reliability test of the variable interest in entrepreneurship students

\begin{tabular}{c|c|c}
\hline \hline $\begin{array}{c}\text { N of } \\
\text { items }\end{array}$ & $\begin{array}{c}\text { Cronbach's } \\
\text { Alpha }\end{array}$ & Remark \\
\hline 13 & 0,791 & Reliable \\
\hline \hline
\end{tabular}

Studying of the Table 5 can be inferred that the 14 statements tested all of them generate value significance $<0.05$ so all the valid statements as an instrument of free variables are now the effectiveness of learning life skills.

Table 5. The validity test of the variable effectiveness of learning life skills

\begin{tabular}{c|c|c|c}
\hline \hline No. & $\begin{array}{c}\text { Pearson } \\
\text { Correlation }\end{array}$ & Sig. & Remark \\
\hline 1 & 0,543 & 0,000 & Valid \\
\hline 2 & 0,660 & 0,000 & Valid \\
\hline 3 & 0,586 & 0,000 & Valid \\
\hline 4 & 0,550 & 0,000 & Valid \\
\hline 5 & 0,651 & 0,000 & Valid \\
\hline 6 & 0,623 & 0,000 & Valid \\
\hline 7 & $-0,068$ & 0,527 & Invalid \\
\hline 8 & 0,373 & 0,000 & Valid \\
\hline 9 & 0,662 & 0,000 & Valid \\
\hline 10 & 0,541 & 0,000 & Valid \\
\hline 11 & 0,553 & 0,000 & Valid \\
\hline 12 & 0,528 & 0,000 & Valid \\
\hline 13 & 0,644 & 0,000 & Valid \\
\hline 14 & 0,437 & 0,000 & Valid \\
\hline 15 & 0,518 & 0,000 & Valid \\
\hline \hline
\end{tabular}

The results of the analysis of the value of the Cronbach's Alpha is 0.827 this shows that now are also reliability (reliable) to be used to measure the effectiveness of the independent variables of learning life skills (see Table 6).

Table 6. The reliability test of the variable effectiveness of learning life skills

\begin{tabular}{c|c|c}
\hline $\begin{array}{c}\text { N of } \\
\text { items }\end{array}$ & $\begin{array}{c}\text { Cronbach's } \\
\text { Alpha }\end{array}$ & Remark \\
\hline 14 & 0,827 & Reliable \\
\hline \hline
\end{tabular}

The analysis is shown before doing the regression test. The fisrt normality test is done to determine whether the data has been collected Gaussian. The analysis is shown Table 7 and Table 8 the significance value obtained is greater than 0.05 that it can be concluded that data Gaussian. 
Table 7. The normality test for the effectiveness of life skills with values entrepreneurship

\begin{tabular}{c|c|c|c}
\hline \hline Variable & $\begin{array}{c}\text { Kolmogorov- } \\
\text { Smirnov Test }\end{array}$ & Sig. & Remark \\
\hline $\mathrm{X}-\mathrm{Y}_{1}$ & 0,662 & 0,773 & Normal \\
\hline \hline
\end{tabular}

Table 8. the normality test for the effectiveness of life skills with an interest in entrepreneurship

\begin{tabular}{c|c|c|c}
\hline \hline Variable & $\begin{array}{c}\text { Kolmogorov- } \\
\text { Smirnov Test }\end{array}$ & Sig. & Remark \\
\hline $\mathrm{X}-\mathrm{Y}_{2}$ & 0,675 & 0,752 & Normal \\
\hline \hline
\end{tabular}

The Linearity test is used to find out whether independent variables (X 1) and a dependent variable (Y1 and Y2) have a linear relationship significantly or not. The results of testing linearity variables $\mathrm{X} 1$ and $\mathrm{Y} 1$ Deviation from the results obtained with the significance of the Linear $0.317>0.05$ (see Table 9).

Table 9. The linearity test variable $\mathrm{X}_{1}$ and $\mathrm{Y}_{1}$

\begin{tabular}{c|c|c}
\hline \hline Variable & $\begin{array}{c}\text { Sig. } \\
\text { Deviation from Lineary }\end{array}$ & Remark \\
\hline X dengan $\mathrm{Y}_{1}$ & 0,317 & Linear \\
\hline \hline
\end{tabular}

The effectiveness life skills education and values Entrepreneurship have a linear relationship. The results of linearity test variables $\mathrm{X} 1$ and $\mathrm{Y} 2$ deviation from the results obtained with the significance of the Linear $0.172>0.05$ (see Table 10). The effectiveness and interest in entrepreneurship have also a linear relationship.

Table 10. The linearity test variable $X_{1}$ and $Y_{2}$

\begin{tabular}{c|c|c}
\hline \hline Variable & Sig. & Remark \\
\hline $\mathrm{X}$ dengan $\mathrm{Y}_{2}$ & 0,172 & Linear \\
\hline \hline
\end{tabular}

The formulation of hypothesis test that the effectiveness of life skills education in fostering values and entrepreneurial is interest in elementary school of Muhammadiyah. 
Table 11. The results of the regression variable $X_{1}$ and $Y_{1}$

\begin{tabular}{c|c|c|c|c}
\hline \hline Variable & $\begin{array}{c}\text { Coefficiens } \\
\text { Regresi (B) }\end{array}$ & $\mathrm{t}$ & Sig. $\mathrm{t}$ & Remark \\
\hline Constant & 54,814 & 9,813 & 0,000 & \\
\hline $\begin{array}{c}\text { Values of } \\
\text { entrepreneurial }\end{array}$ & 0,404 & 3,401 & 0,001 & Significant \\
\hline Std. Coefficient & 0,341 & & & \\
\hline R Square & 0,116 & & & \\
\hline \hline
\end{tabular}

The hypothesis was tested:

$\mathrm{H}_{0}=$ there is no influence of learning life skills in fostering entrepreneurship students elementary school of Muhammadiyah.

$\mathrm{H}_{1}=$ there is the influence of learning life skills in fostering entrepreneurship students elementary school of Muhammadiyah.

Table 11 shows the result of the value of the Coefficients is known the value of Sig $0.001<0.05$. It can be inferred that there is an influence of learning life skills in fostering entrepreneurship students grades primary school Muhammadiyah. The R-value of Square produced in the Model Summary is 0.116 which means that influence the learning of life skills in fostering values entrepreneurship students primary school Muhammadiyah is $11.6 \%$.

Table 12. The results of the regression variable $X_{1}$ and $Y_{2}$

\begin{tabular}{c|c|c|c|c}
\hline \hline Variable & $\begin{array}{c}\text { Coefficiens } \\
\text { Regresi (B) }\end{array}$ & $\mathrm{t}$ & Sig. t & Remark \\
\hline Constant & 24,293 & 6,193 & 0,000 & \\
\hline $\begin{array}{c}\text { Interest in } \\
\text { entrepreneurial }\end{array}$ & 0,264 & 3,358 & 0,001 & Significant \\
\hline Std. Coefficient & 0,337 & & & \\
\hline R Square & 0,114 & & & \\
\hline \hline
\end{tabular}

The hypothesis was tested:

$\mathrm{H}_{0}=$ there is no influence of learning life skills in growing interest in entrepreneurship student elementary school of Muhammadiyah.

$\mathrm{H}_{1}=$ there is the influence of learning life skills in growing interest in entrepreneurship student elementary school of Muhammadiyah.

Table 12 shows the result of the value of the Coefficients is known the value of Sig $0.001<0.05$. It can be inferred that there is an influence of learning life skills in growing interest in the entrepreneurship student elementary school of Muhammadiyah. The R-value of Square produced in the Model Summary is 0.114 which means that influence the learning of life skills in growing interest in entrepreneurship students elementary school of Muhammadiyah was $11.4 \%$.

Kurniawan, B., Sayuti, M., \& Kuat, T. (2018). The effectiveness of life skills education in fostering entrepreneurship values and interest of primary school students. Journal of Vocational Education Studies, 1(1), 21-28. D0I: https://doi.org/10.12928/joves.v1i1.592. 


\section{CONCLUSION}

Life skills education activities make the learning conditions of students to be varied. Early entrepreneurship education can be given since primary school. The analysis can be concluded that learning life skills education in primary school is effective in fostering entrepreneurship value and students interest in entrepreneurship of $23 \%$.

\section{REFERENCES}

Cunha, F., \& Heckman, J. (2007). The technology of skill formation. American Economic Review, 97(2), 31-47.

Huber, L. R., Sloof, R., \& van Praag, M. (2014). The effect of early entrepreneurship education: Evidence from a field experiment. European Economic Review, 72, 76-97.

Indrasutanto, T. (2017). Kurikulum Berbasis Kompetensi dan Pendidikan Kecakapan Hidup (Life Skill Education). Magister Scientiae, 23, 1-29.

MOEC. (2013). Peraturan Menteri Pendidikan dan Kebudayaan Nomor 54 tahun 2013 tentang Standar Kompetensi Lulusan Sekolah Menengah Kejuruan. Jakarta: Ministry of Education and Culture.

Ristekdikti. (2016). Undang-Undang nomor 20 tahun 2003 tentang Sistem Pendidikan Nasional. Retrieved from: https://kelembagaan.ristekdikti.go.id/wpcontent/uploads/2016/08/UU_no_20_th_2003.pdf

Robles, M. M. (2012). Executive perceptions of the top 10 soft skills needed in today's workplace. Business Communication Quarterly, 75(4), 453-465.

WHO. (1993). Skill for Health. Atlanta: World Health Organization. 